\title{
Preparing HS Students to Succeed in STEM Fields via an Early College Experience (Evaluation)
}

\section{Dr. Kathryn Schulte Grahame, Northeastern University}

Dr. Kathryn Schulte Grahame is an Associate Teaching Professor at Northeastern University and a member of the first-year engineering team. The focus of this team is on providing a consistent, comprehensive, and constructive educational experience that endorses the student-centered, professional and practiceoriented mission of Northeastern University. She teaches the Cornerstone of Engineering courses to firstyear students as well as courses within the Civil and Environmental Engineering Department. She is a recent recipient of the Outstanding Teacher of First-Year Students Award and is interested in research that compliments and informs her teaching.

\section{Dr. Christos Zahopoulos, Northeastern University}

Christos Zahopoulos is tenured Associate Professor at Northeastern University, with appointments in the Graduate School of Education, the Department of Physics and the Gordon Institute of Engineering Leadership. He also is the Founder and the former Executive Director of Northeastern University's Center for STEM Education. For more than 30 years, Professor Christos Zahopoulos has been actively involved in STEM Education at the local, state and national levels, playing a key role in initiating and implementing numerous STEM Education programs and partnerships, which have received more than $\$ 30$ million in grants and gifts. He has served in numerous STEM Education Boards, including the Governor's STEM Advisory Council. Professor Zahopoulos received his Ph.D. degree in Physics from Northeastern University and was a Postdoctoral Research Fellow in the Division of Applied Sciences at Harvard University.

\section{Ms. Rajini Jesudason, Northeastern University}

Raj Jesudason is a mathematics instructor at Northeastern University. Raj's passion is to empower underserved communities through mathematics education. Raj has worked with the Boston Public Schools as a mathematics Program Director and has worked at various universities like Harvard, Wellesley, UMass Boston and Wheelock Colleges. Raj has also been a Dean of Physical Sciences, Mathematics and Engineering at a community college in California and has helped to implement initiatives in asset-based instruction in Boston School District. Raj has lived and worked abroad (Africa/Asia) and is interested in tying quality research to the practice of those in the field and community. 


\section{Preparing HS Students to Succeed in STEM Fields via an Early College Experience K-12 Division (Evaluation)}

\section{Introduction}

Across the U.S. there are many growing innovation clusters, one of which is clean energy. In one state, this is due in part to the 2008 Global Warming Solutions Act (GWSA), which mandates that greenhouse gases be reduced in the state to $25 \%$ below 1990 levels by 2020 , and $80 \%$ by 2050 [1]. To address the growing need for investment in job creation, a private university, an urban high school, and an industry partner collaborated to create a program for high schoolers to instill excitement in this growing field. Specifically, this program addresses the increasing need for a diverse and highly skilled STEM (Science, Technology, Engineering and Math) workforce with a focus on Clean Energy. The program was designed to:

- Offer an introductory engineering design course which used project-based learning applying principles of clean energy to a real-life situation for college credit

- Increase student content knowledge in STEM, in general, and clean energy, in particular

- Improve students' attitudes toward interest in, and confidence with STEM and Clean Energy content, as well as future careers in these sectors

- Increase students' preparedness for college expectations

This program was made possible via three annual grants from the Massachusetts Clean Energy Center, in-kind contributions from the educational institutions, and the industry partners, who volunteered company time and resources. The program design was based on a review of existing research which led to the development of a logic model--a graphic illustration of the theory of change -- (See Appendix A). The logic model illustrates the logical relationship among program inputs (such as the grant funds and faculty expertise), activities (such as the introductory engineering design course) and desired outputs (such as numbers of participating students) and outcomes (such as increases in student interest in clean energy careers). This logic model was used to inform the program design, including activities with students. In addition, the logic model was used to frame measures of success. This paper will describe our efforts, examine the measurements of our goals, and discuss lessons learned over the three iterations of our program.

\section{Background}

Three different cohorts of students participated in the program between 2013-18. Each cohort experienced similar recruitment strategies, participated in similar coursework, and were provided with hands-on experiences. In this section, we provide an overview of the overall program and follow with information about how the program differed across cohorts. 


\section{Cohort Selection}

Across all cohorts, district personnel identified likely students to participate in the program. The district personnel sought students who were taking advanced mathematics and who had expressed interest in STEM. The university then offered an Open House for students and their families to inform them about the program, its expectations and desired commitment and give them the opportunity to ask questions.

The program design differed across cohorts in several keyways. The first cohort of students were recruited from several public high schools in Boston. The application process included a teacher recommendation, transcript, personal essay, and an in-person interview. Students needed to demonstrate a genuine interest in pursuing a STEM field, as well as the ability and drive to succeed. Special attention was given to applicants who were underrepresented in STEM fields. Via this intensive application process, twenty-five students from nine different schools were selected to be part of this cohort.

In contrast, the second and third cohorts of students were selected from a single school, as per requirement by the funder. The application process was designed, managed, and verified by the partner high school's Science Director, who screened candidates based on their math and science grades. Students' grades were kept private, but the director recommended against a candidate moving past the initial application if grades in math and science were low. The Science Director worked closely with the students and families through the application process. Selected students were juniors and seniors.

\section{Cohort Demographics}

Across all cohorts, the project aimed to recruit a diverse set of students to participate in the interaction. Table 1 illustrates the demographic characteristics of participants across all cohorts.

Across all cohorts, the project offered engineering content to students and an early college experience. However, the project engaged in somewhat different activities across cohorts. For the brevity of this paper, a longer description of each model, its final projects, and incentives are provided in Appendix B. A summary of the major differences between the models is provided in Table 2 with a more detailed explanation of the rationale between iterations provided in Appendix B. While there are differences across the cohorts, all cohorts shared four major components: (1) college credit, (2) AP calculus support, (3) college advice, and (4) industry panelists. 
Table 1. Demographic Characteristics of Students Participating in the Project by Cohort

\begin{tabular}{|c|c|c|c|c|c|c|}
\hline \multirow[b]{2}{*}{ Racial/Ethnic Category } & \multicolumn{2}{|c|}{$\begin{array}{c}\text { Cohort } 1 \\
2013-2014 \\
\end{array}$} & \multicolumn{2}{|c|}{$\begin{array}{c}\text { Cohort } 2 \\
2014-2015 \\
\end{array}$} & \multicolumn{2}{|c|}{$\begin{array}{c}\text { Cohort } 3 \\
2017-2018 \\
\end{array}$} \\
\hline & $\mathbf{N}$ & $\%$ & $\mathbf{N}$ & $\%$ & $\mathbf{N}$ & $\%$ \\
\hline $\begin{array}{l}\text { African American, } \\
\text { African or Caribbean }\end{array}$ & 5 & $24 \%$ & 6 & $22 \%$ & 3 & $15 \%$ \\
\hline Latino or Brazilian & 4 & $19 \%$ & 1 & $4 \%$ & 2 & $10 \%$ \\
\hline Asian & 10 & $48 \%$ & 16 & $65 \%$ & 14 & $7 \%$ \\
\hline Middle Eastern & 0 & $0 \%$ & 0 & $0 \%$ & 0 & $0 \%$ \\
\hline Not reported or mixed & 2 & $9 \%$ & 2 & $9 \%$ & 1 & $5 \%$ \\
\hline Total & 21 & $100 \%$ & 25 & $100 \%$ & 20 & $100 \%$ \\
\hline Gender & $\mathbf{N}$ & $\%$ & $\mathbf{N}$ & $\%$ & $\mathbf{N}$ & $\%$ \\
\hline Male & 14 & $67 \%$ & 16 & $65 \%$ & 14 & $70 \%$ \\
\hline Female & 7 & $33 \%$ & 9 & $35 \%$ & 5 & $25 \%$ \\
\hline Non-binary & 0 & $0 \%$ & 0 & $0 \%$ & 1 & $5 \%$ \\
\hline
\end{tabular}

Table 2. Summary of Program Models

\begin{tabular}{|l|c|c|c|}
\hline & Cohort 1 & Cohort 2 & Cohort 3 \\
\hline College Credit & $\mathrm{x}$ & $\mathrm{x}$ & $\mathrm{x}$ \\
\hline AP Calculus support & $\mathrm{x}$ & $\mathrm{x}$ & $\mathrm{x}$ \\
\hline College advice & $\mathrm{x}$ & $\mathrm{x}$ & $\mathrm{x}$ \\
\hline Industry Panel & & $\mathrm{x}$ & $\mathrm{x}$ \\
\hline Dedicated Industry Partner & & $\mathrm{x}$ & $\mathrm{x}$ \\
\hline Hands-on project & & $\mathrm{x}$ & $\mathrm{x}$ \\
\hline Real-life monitoring project & & & $\mathrm{x}$ \\
\hline Scholarship Prizes for best designs & & & $\mathrm{x}$ \\
\hline Scholarship Incentive for earning A/B & & & \\
\hline Paid working hours for project work time & & & \\
\hline Field Trips to Clean Energy Centers & & & $\mathrm{x}$ \\
\hline
\end{tabular}




\section{Description of Methodological Approach}

Across all three cohorts, data were collected using a mixed-methods approach. The external evaluator and the faculty coordinated with the Institutional Review Board (IRB) prior to collecting data. This research paper is based on secondary analysis of data collected for the evaluation. Table 3 presents a summary of data collection activities across all three cohorts.

Table 3. Data Collection Activities

\begin{tabular}{|c|c|c|c|c|}
\hline $\begin{array}{c}\text { Data } \\
\text { Collection } \\
\text { Activity }\end{array}$ & Description & Cohort 1 & Cohort 2 & Cohort 3 \\
\hline \multirow{2}{*}{$\begin{array}{c}\text { Observations } \\
\text { and informal } \\
\text { data } \\
\text { collection }\end{array}$} & $\begin{array}{l}\text { Number of Leadership Team } \\
\text { meetings/conference calls }\end{array}$ & 2 & 2 & 4 \\
\hline & $\begin{array}{l}\text { Observations of instructors, teachers } \\
\text { and students }\end{array}$ & 2 & 1 & 2 \\
\hline \multirow{6}{*}{$\begin{array}{l}\text { Surveys, } \\
\text { interviews } \\
\text { and focus } \\
\text { groups }\end{array}$} & $\begin{array}{c}\text { Number of students who responded to } \\
\text { interim survey }\end{array}$ & 17 & 22 & 13 \\
\hline & $\begin{array}{l}\text { Number of students who responded to } \\
\text { final survey }\end{array}$ & 18 & 20 & 21 \\
\hline & Number of student focus groups & 1 & 1 & 2 \\
\hline & Number of student participants & 16 & 19 & 17 and 20 \\
\hline & $\begin{array}{l}\text { Number of faculty and mentor focus } \\
\text { groups/informal interviews }\end{array}$ & 12 & 2 & 15 \\
\hline & $\begin{array}{l}\text { Follow up surveys administered in } \\
2019-2020 \\
\text { Number of students } \\
\text { Number of mentors }\end{array}$ & \multicolumn{3}{|c|}{ Cohort not specified } \\
\hline $\begin{array}{l}\text { Document } \\
\text { review }\end{array}$ & \multicolumn{4}{|c|}{ Project communications, Course Materials, and Student Project PowerPoints } \\
\hline
\end{tabular}


The quantitative analyses included descriptive statistical analyses to determine frequencies and averages and dependent sample t-tests to determine changes in students' pre and post-test knowledge. The qualitative methods were guided by Miles \& Huberman's framework of creating an initial coding schema, refining the codes after preliminary analysis, and exploring emerging themes and trends [2]. Qualitative data were coded based on a schema that examined the relationship between actors (such as faculty and mentors), activities (such as the mentoring supports), outputs (such as number of students and hours the course was offered) and desired outcomes (such as interest in STEM) and confidence to succeed in college.

\section{Findings: Analysis \& Results}

The findings below summarize data reported in the annual evaluation reports along with the newly collected student and mentor data. The section begins with a summary of key findings across cohorts, then describes differences across them and it concludes with findings from project mentors.

\section{Students Across All Three Cohorts Reported Benefits of the Program}

Across all cohorts, students reported increases in knowledge, skills and confidence based on analysis of pre-participation and post-participation surveys. In qualitative responses, students attributed the increases to the content of the course, the hands-on learning experiences, the faculty and mentors, faculty and support from school administrators, and experiences learning from their peers.

A follow up survey administered in the fall 2019 in which 19 former students participated, 90\% of respondents reported that they were either working in a STEM field or studying STEM. Of those who responded, $89 \%$ reported that the program helped them to understand what to expect in college, $71 \%$ reported that it helped them succeed in college, and over half (56\%) reported that their participation in the program was one reason they decided to pursue STEM.

Students who completed the follow up survey in the fall 2019 reported the benefits of the ECE program. Examples of the benefits reported are presented below:

The NEU Clean energy and engineering course was one of the best things I had done in high school. It truly motivated me to go into STEM and also really inspired me to pursue sustainable lifestyles. This course was also one of the first truly hands-on project-based courses of my high school career and it gave me a chance to learn a lot about myself as a teammate, an engineer, and a student. This course also has influenced the way I see education and also my interactions with "authority figures" like professors and mentors. It was a truly positive and productive environment for me and I would do it again in a heartbeat. 
The clean energy project I have done in this program definitely shaped my decisions about education, it not only drives me to think critically as an engineer but also helps strengthen my determination in getting involved in the Engineering field.

The project that we did in the program really allow[ed] me [learn] to how to work as a team and how with a good team that communicates, we are able to get things done. In addition to that I was able to learn to not be afraid to ask questions because no matter if you think your question is dumb it can be very useful to a class in general.

That course really was the deciding factor for me in the process of choosing what I wanted to do. It captivated me and launched me into my current academic and career path! I am very happy to have done it my last year of high school!

I think the people of this program have become great mentors in my experience today, whether they know it or not.

This course had inspired me as an engineer, scholar, and a dreamer to reimagine problem solving as a collaborative, hands on experience that surprisingly was fun despite being academic. Taking NEU's Clean Energy and Engineering has brought me to where I am- a woman of color, queer, recent first-generation college graduate because of the incredible role models, brilliant female professor, hands on interactive and relevant content, and my peers.

\section{Students' Content Knowledge was Comparable to Northeastern College Students'}

For selected cohorts, secondary analysis of student exam data was performed. The exams administered to the ECE high school students were identical to those given to the college students to allow for comparison. Because only summary data were available, the research team only reports the descriptive summary data. Analysis found that the students participating in the 2014-2015 academic year appeared to perform better than those who participated in the previous year. Moreover, the 2014-2015 students performed similarly to Northeastern students. Table 4 shows the average midterm and final grades of the ECE students compared to college students taking the same course with the same professor.

Separately, on a post-course survey, students reported that they felt they had gained engineering and clean energy content knowledge. On a 5 -point scale $(1=$ strongly disagree to $5=$ strongly agree), students across all cohorts strongly agreed that the course increased their content knowledge in Engineering Design. 
Table 4. Comparison of Average Exam Scores for Same Professor

\begin{tabular}{|c|c|c|c|c|c|c|c|c|c|c|}
\hline & \multicolumn{5}{|c|}{ High School Students } & \multicolumn{5}{|c|}{ College Students } \\
\hline & \multicolumn{2}{|c|}{$\begin{array}{c}2013-14 \\
\text { (cohort 1) }\end{array}$} & \multicolumn{2}{|c|}{$\begin{array}{l}2014-15 * \\
\text { (cohort 2) }\end{array}$} & $\begin{array}{c}2017-18 \\
\text { (cohort 3) }\end{array}$ & \multicolumn{2}{|c|}{ 2013-14 } & \multicolumn{2}{|c|}{ 2014-15 } & 2017-18+ \\
\hline $\begin{array}{c}\text { Number } \\
\text { of } \\
\text { students }\end{array}$ & \multicolumn{2}{|c|}{23} & \multicolumn{2}{|c|}{23} & 20 & \multicolumn{2}{|c|}{57} & \multicolumn{2}{|c|}{94} & 117 \\
\hline Exam & $\begin{array}{l}\text { Mid- } \\
\text { term }\end{array}$ & Final & $\begin{array}{l}\text { Mid- } \\
\text { term }\end{array}$ & Final & Final & $\begin{array}{l}\text { Mid- } \\
\text { term }\end{array}$ & Final & $\begin{array}{l}\text { Mid- } \\
\text { term }\end{array}$ & Final & Final \\
\hline Average & 79.0 & 74.7 & 82.6 & 87.3 & 84.8 & 88.2 & 86.6 & 89.9 & 86.7 & 87.1 \\
\hline
\end{tabular}

* indicates class with intervention: real life project instead of traditional

+ In 2017-18, the college course changed, eliminating the midterm. Therefore, Cohort 3 high school students and comparison college students did not take a midterm.

\section{Challenges and Successes Across Cohorts}

Some differences were found across cohorts. Below, we briefly summarize key challenges and successes across each cohort.

\section{Challenges and Successes from Cohort 1}

In cohort 1, the project goal was to recruit 20 students. The project exceeded this original goal by registering and graduating 23 students despite the lack of a stipend for completion of the program. Students were required to dedicate two days a week after school to the program, even though they had competing obligations, like after school clubs and other Advanced Placement (AP) school-based opportunities, sports, after school jobs, and family needs. This contributed to the difficulty the students had maintaining the challenge of college level work. Exam grades were compared to those of first-year university students taking the course with the same instructor. The grade distribution was lower than the university students' and this was attributed to a need for more mentor support for the cohort and greater incentives for doing well.

\section{Challenges and Successes from Cohort 2}

As discussed in our previous work [3], exams administered to the High School students (with identical questions to those given to the university students) showed improved average exam scores for the high school students as compared to Cohort 1. Notably, Cohort 2 students who 
participated in the program scored slightly higher on average compared with university students on their final exams.

Another accomplishment resulted from students' participation in a city-wide Energy Conservation Challenge. The challenge was designed to engage students in presenting clean energy proposals designed to achieve the greatest electricity reduction compared to baseline. A team consisting of students from our program proposed school-wide changes in the facilities, won the competition and their school received $\$ 10,000$ from the city's Facility Management to use for building improvements, based on their recommendations. As a result of the changes in the facility, the schools saved the complex over $\$ 20,000$ in just three months after making the changes proposed by the participating students.

Our research found that Cohort 2 also found that a majority of students who were eligible reported that they would be attending their first-choice college. Students were asked about their future plans and nearly all of the students who responded to the final survey reported that they were planning to attend their first-choice college. Most of the participating students were graduating seniors, but 6 were juniors and reported that they would be attending high school next year. Of the graduating seniors (who completed the year-end survey), all reported that they would be attending higher education the following year. Moreover, all students were accepted into one of their top choice colleges/universities. All but one reported that they planned on attending a top choice college or university. The one student who reported he would not be attending a top choice reported that he planned on attending community college first to defray costs. He indicated that he hoped to attend his first-choice university after completing basic requirements at the lower-cost community college.

Analysis of qualitative data suggests that the industry partnership, hands-on activities, stipend incentives and the support of the mentors were the main contributing factors to the success of the program.

\section{Challenges and Successes from Cohort 3}

Analysis of data from Cohort 3 found that most of the challenges and successes reported for Cohort 2 were also experienced by Cohort 3. One unique success of Cohort 3 that was documented was the opportunity students had to "Learn and Earn" - where students were paid to complete hands-on projects, outside of the instructor-led, engineering design course hours.

Cohort 3 students reported that they gained valuable job experience, as they were accountable for logging hours, completing projects, working in teams, during the application period of the program. They were able to learn the basic technical part of the program before the Engineering Design course started, so it made the course run more smoothly. However, this also meant that they were learning the programming without the context of the course or project, which made initial learning more difficult for some. 


\section{Importance of Mentors' Role in the Early College Experience Across Cohorts}

Research supports the importance of the role of mentors in the students' success in underserved communities [4]. Mentors not only provide academic support and knowledge to the students, but they act as role models and share success stories and strategies to navigate larger academic and professional communities, which can be daunting for some students unfamiliar with such institutions [5]. Research also shows the positive impact of successful role models and the alleviation of performance deficit and stereotype threat in mathematics for women [6] as well as the positive impact of mentors who formed instrumental and socioemotional relationships with students [7] and role models who achieved successes perceived as attainable and realistic [8]. We thus included mentors who were successful college students from similar backgrounds to the students. The mentors also assisted the instructors and acted as a natural liaison between the high school students and the instructors and administrators of the program.

The mentors were primarily undergraduate or graduate students from our university and other local institutions, generally majoring or working in STEM fields. The mentors recorded student attendance, graded homework assignments, and assisted in class in many ways. They provided administrative support for the PI and Program Manager and helped with the smooth operation of meetings and events. Generally speaking, they also served as role models and conversed with students about college life. Mentors were guaranteed between 5-10 hours of work per week at a rate of $\$ 15$ per hour for the duration of the program.

In Cohort 1, the mentors primarily acted as tutors and administrative assistants. The lead mentor who was representative of the community, provided valuable insight in getting the students to achieve a high level of success and professionalism while balancing challenging work, academic and family needs. In cohorts 2 and 3 the mentors took on a more primary teaching role for adjunct activities, such as project guidance as well as lectures in technology like SolidWorks, AutoCAD and Excel. Mentors developed their own skills, as many had never led instruction. The interchange of information between the urban high school students and the mentors also provided opportunities for both parties to grow. Some mentors even chose to sit in on optional lectures/activities. Several alumni from previous cohorts of the Early College Experience went on to be mentors in other programs.

\section{Mentor Results}

A survey of the mentors that was administered in the winter 2019/20 revealed that mentors reported several benefits from the experience. A total of six mentors completed the survey, three of whom were female. Two of the six were working in STEM-related careers and four were students. Of those working in STEM, one was working as a civil engineer and the other was working as a software engineer. The four other mentors were studying STEM. 
All of the mentors $(100 \%)$ who responded reported that their experience increased their confidence in teaching or being a teaching assistant, facilitating group work, supporting hands-on learning, explaining complex STEM topics to students, and engaging with faculty. Mentors elaborated on these ratings:

The Clean Energy program strengthened my ability towards the research and problem solving.

Helps me learn more on why clean energy is important and how to use STEM technique to approach it.

The Clean Energy program was inspiring because of the kids that were selected to be a part of it. It made me realize what a privilege it was to study engineering and that something I'd like to do with my future is make engineering more accessible regardless of social, regional, or economic background.

Overall, mentoring for this program gave me more confidence with the skills needed to be a successful teaching assistant. Working with [the] Professor over the summer definitely pushed me to pursue TA positions for her classes during the school year, which I've now done twice.

Mentors further elaborated on the benefits of the Clean Energy program to themselves and the participating students. One mentor reported, "The biggest strength was making the course tangible and hands on. Having the field trips and making engineering real and applicable to everyday life by doing the energy audit on their own school made a tangible impact on me for material so I know it had an effect on them too." Another stated, "Something that hasn't been brought up in this survey yet that I think is really beneficial is the way this program inspires high school students and gives them an opportunity to take a university-level course and get a sense of what pursuing engineering in college might look like."

\section{Conclusion}

This Early College Experience (ECE) program was made possible through a collaborative relationship between a university, industry, and high school partner. With monetary incentives provided by a state grant, university credits were offered to high school students completing a first-year engineering design course. Students were tasked with completing projects on the topic of clean energy relating to the students' lives and their final projects were made accountable to the members of their community. University age mentors were employed to support students with their work and encourage their success. Additional advanced placement (AP) calculus tutoring and college application and scholarship advice were also offered to the students through this program. 
These unique aspects of the program led to desired improvements as well as unexpected outcomes. Participating students reported increases in confidence in STEM and an increased interest in clean energy. In addition, mentors reported benefits from the program. Follow-up surveys administered years after the program revealed that students and mentors found the unique aspects of coursework, hands-on experiences, and engagement with industry professionals were viewed as beneficial to participating students.

To summarize, across all three cohorts of participants, the program achieved the following desired goals:

- Offered an introductory engineering design course for college credit

- Increased student content knowledge in STEM and clean energy

- Improved students' attitudes toward, interest in, and confidence with STEM and Clean Energy content, as well as future careers in these sectors

- Increased students' perceptions of their preparedness for college expectations

Data collected over the past three years reveals that the ECE program, a partnership among an urban university, an urban high school and a local industry partner, appears to be a promising model of engaging minority and economically disadvantaged students in an early college experience. Moreover, analysis of qualitative data reveals that students were very positive about the focus on a real-life engineering design project. As institutions of higher education consider methods of engaging typically under-represented youth in engineering, this project provides a useful model as to what can be achieved by students. 


\section{Appendix A - Grant Logic Model}

Learn \& Earn Logic Model

\begin{tabular}{|c|c|}
\hline Inputs & Activities \\
\hline $\begin{array}{l}\text { Project Director } \\
\text { and faculy } \\
\text { knowledge and } \\
\text { skils } \\
\text {. NEU rescurces } \\
\text { and creditbearing } \\
\text { courses } \\
\text {. Signar Success } \\
\text { curriculum } \\
\text { Freshman } \\
\text { Engineering } \\
\text { Design course } \\
\text { - Mentors and } \\
\text { supports } \\
\text { - Students' } \\
\text { attiludes, } \\
\text { background } \\
\text { knowledge, and } \\
\text { demographic } \\
\text { characteristics }\end{array}$ & $\begin{array}{l}\text { - Project leaders plan detailed timeline } \\
\text { - Project leaders recruit students to participate in the } \\
\text { - ECE project } \\
\text { - ECE project offers Signal Success curriculum at the } \\
\text { - Sohn D. O'Bryant School } \\
\text { - Students collect data for project } \\
\text { - NEU offers supports including mentoring to assist } \\
\text { students: a) in obtaining key energy content } \\
\text { knowledge; b) understanding the process of applying } \\
\text { for college; and c) improving the transition from high } \\
\text { school to college } \\
\text { - NEU offers Freshman Engineering Design course with } \\
\text { focus on clean energy } \\
\text { - NEU offers panel discussions and field trips focusing } \\
\text { on clean energy } \\
\text { - Independent evaluator collects survey, assessment } \\
\text { and other formative and summative evaluation data to } \\
\text { inform future courses and supports and to document if } \\
\text { project has met desired benchmarks }\end{array}$ \\
\hline
\end{tabular}

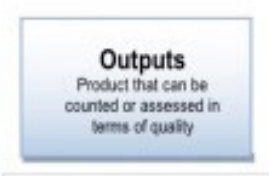

- Number of students recruited by demographic group

- Number of students who complete their clean energy project

- Number of students who complete the Engineering Design course

- Number of students who successfully complete all aspects of the project

- Students' perspectives of the quality of activities including mentors and supports

- Evaluation findings and recommendations

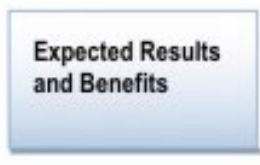

- Students receive 3 credts for completing the

Engineering Design course

- Students report improved

attitudes voward, interest

in, and confidence with

STEM content and the

Clean Energy sector

- Students report feeling better prepared for college and mare confisent with he college application process

- Students demonstrate improved content knowledge in STEM and energy

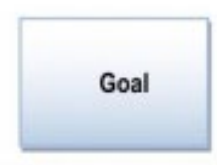

- Improve student STEM content knowledge and interest pursuing careers in the Clean Energy sector 


\section{Appendix B-- Details about Each Cohort}

\section{Cohort 1}

\section{Overview}

The first cohort met at the university from mid-fall of 2013 to April of 2014. This cohort was enrolled for transferable credit in the College of Engineering freshman design course taught by a university instructor who also taught this course concurrently with university freshman. The program course used the same syllabus, projects and metrics as the college level course, but was spread out over two semesters. This change was made to accommodate students' schedules because each of the selected high school students were taking a full, rigorous high school course load. Additionally, many of the activities and homework had to be adapted to accommodate the new time scale of a two-semester class and the differences in student accessibility to engineering computer programs.

Additional components for the program that were not typical to a freshman student experience included: one mentor for the high school students consisting of a university undergraduate students who had recently completed the course; additional sessions on college applications and scholarship opportunities given by the university admissions team; and AP calculus tutoring.

In Cohort 1, students were required to attend an AP Calculus/Math prep for the first hour. Students brought in their math homework and were instructed/tutored by a high school teacher and a university lecturer who helped them prepare for AP Calculus (or precalculus if they were a junior). A variety of high school teachers also offered guest lectures. After the math support, students took for university credit, a course in Engineering Design, led by a university professor. Students were able to earn college credit through the College of Engineering. Guest speakers providing advice on college opportunities were given full class times throughout the experience during instructional time.

\section{Final Project Description}

The course assigned a hypothetical sustainable home design project. Students were tasked with finding sustainable means to deliver power and water to their homes as well as suggesting sustainable materials that might make up the home. Each of these components was scaffolded through a series of group research assignments. The final deliverables for the project included a CAD drawing of the students' proposed home with water and electrical plans mapped with inputs and outputs. Students were also tasked with summarizing and justifying their choices in a 20-minute group presentation at the end of the semester. 


\section{Incentives}

High school students participating in the first cohort were offered the ability to enroll in a transferable, 4-credit, first-year engineering design course at the partnering university. Students attended this course after their normal school hours and were provided snacks. They were additionally provided AP Calculus/math tutoring by math instructors before each engineering class.

\section{Cohort 2}

\section{Overview}

The second cohort of the program (2014-2015) were enrolled in the same College of Engineering design course for credit over two semesters, with the major change being that the course final design project was now involved a year-long, real-life project to design improvements in energy efficiency for the students' own high school (also referred to as an energy audit.) The grant funding was increased to provide small scholarships to students who earned an A of B in the course as an incentive. Undergraduate mentors on this project were selected from university students with experience in energy auditing to guide the high school students with their work. An industry partner was brought on to expose students to a working engineer and assist in the program. This partner volunteered the supply of measurement tools, engineering drawings, and advice to students as they collected data about their school for this project. Students worked in groups to collect and analyze data and findings from the audit. They delivered their final audit results and design recommendations in a presentation to city officials and school administrators at the conclusion of the project.

In Cohort 2, students had math support but not in a formal way (students could stay after class to get math help from a university lecturer and math tutors). Students were able to get college credit for an Engineering Design course.

\section{Final Project Description}

For the final project, students worked with the industry partner to perform an energy audit on their high school. Students began the project by conducting three site visits. The first visit consisted of a walk through the high schools' basement where they were introduced to the various machinery that controlled the heat and water in the building. Students were also shown what the buildings' sensors looked like and taught how the system was programmed for various temperatures during a day. Students also did an external evaluation of their building and were able to take pictures of problem areas utilizing the industry partner's infrared camera to note energy leakage. At the next visit, students received CAD drawings of the school and walked through the school after hours with the industry partner and mentors with auditing experience. Room by room students were guided on how to make observations on their plans and look for 
energy inefficiencies. Students were able to contribute their own experiences in the rooms during the day to create a full assessment that included comfort levels. On the final visit, students were asked to place internet-connected temperature sensors in rooms with identified issues that would take measurements over the course of a month. At the conclusion of a month, students downloaded and evaluated the data using Excel. The observations and results from the three visits were evaluated as a class with guidance from the industry partner. These discussions helped the students to formulate evidence-based recommendations for saving energy in their school. Students were placed in groups and asked to develop a recommendation plan based on maximizing energy savings. The recommendations were presented by the groups at the conclusion of the course.

\section{Incentives}

Students selected for the second cohort were offered a transferable 4-credit college course equivalent to one of the university's first-year engineering courses. Additionally, they were provided an opportunity to build their resumes by performing a real-life energy audit. Students receiving an $\mathrm{A}$ or $\mathrm{B}$ in the course at the end of each semester were given a small scholarship award. At the conclusion of the project, the high school student's parents and administrators, and city officials were invited to attend a presentation of the student's energy audits and recommendations. The special guests from this event voted on the best presentation and those students were awarded another monetary scholarship.

Additional support for the students in this cohort included AP calculus tutoring after each class, mentoring from several college students with engineering experience, presentations from university admissions officers on how to improve their chances in applying to a university.

\section{Cohort 3}

\section{Overview}

The third and most recent cohort was enrolled in a similar course to the previous cohort, this time offered through the College of Professional Studies. The students were selected in the fall of 2017 and began the program with tutoring from mentors in their own school. Once a week, mentors would meet and do activities using the programs that would be utilized in the course. In the fall, students focused on learning Excel and analyzing data sets. In the spring of 2018, mentors focused on Python programming and 3-D modeling software (On-Shape) to further prepare students for the course - which had recently changed at the university level. The new university course had integrated the design course with a programming course. In the summer of 2018, students began the engineering course work with the professor with both design and programming integrated into the curriculum. 
In Cohort 3, students focused only on the course in Engineering Design for university credit since a work readiness (Signal Success) curriculum was added as a requirement to the program. However, the need for math support was still recognized, so students were encouraged to attend a sister program, Bridge to Calculus, to support juniors intending to take AP Calculus in their senior year. Even though this optional program started at 7:30 a.m. and did not offer university credit nor a stipend, more than half of the students opted to take and complete this program in conjunction with the Engineering course. Additionally, students were required to sign a contract of commitment, as they were able to get paid for the hands-on project part of the program, the "Learn and Earn" component. Students had prep in tech, (Python, CAD and Excel), did some instrumentation and then took the Engineering Design course in the summer with a "work-study" component where they built museum-exhibit types of projects that were evaluated by outside judges.

\section{Final Project Description}

For the final project of the course, students were expecting to do another monitoring project with some new energy measuring equipment provided by the grant. Students again performed multiple site visits to learn about the components of a building's energy creation, consumption, and waste. However, due to means outside of the control of the grant team, the newly purchased monitoring equipment was not able to be installed. As a result, there would be no real time data for the students to analyze and the final project needed to be changed. Students were asked to identify issues using their own site visit results and through looking at the previous year's data. In teams they were asked to design and program a hands-on interactive learning module that proposed innovative solutions toward energy saving in their schools. The final presentation of their team designs was then presented in a museum-style exhibition where visitors could learn about the various ways that energy could be saved through each student's unique hands-on interactive model.

\section{Incentives}

Students selected for the third cohort were offered a transferable 4-credit college course equivalent to one of the university's design courses from the College of Professional Studies. All supervised time students worked outside the course on homework and projects was paid at an hourly rate. This monetary incentive was a necessity for students in an urban setting, as the project time was over 20 hours a week, prohibiting many from getting a summer job. At the conclusion of the project, the high school student's parents and administrators, and city officials were invited to attend a presentation of the students' museum-style learning modules. The special guests from this event voted on the best projects and those students were awarded a small monetary scholarship. 
Additional support for the students in this cohort included involvement in a pre-calculus program for rising seniors before the engineering design class, mentoring from several college students with engineering experience, presentations from university admissions officers on how to improve their chances in applying to a university.

\section{References}

[1] M. Governement, "Global warming solutions act background," [Online]. Available: https://www.mass.gov/service-details/global-warming-solutions-act-background.. [Accessed 20 December 2019].

[2] A. M. Huberman and M. B. Miles, Qualitative data analysis: An expanded sourcebook (2nd ed.), Sage Publications, Inc., 1994.

[3] K. Schulte Grahame, C. Zahopoulous and D. Schilder, "Can Real-Life Projects in Freshmen Engineering Classes Result in Improved Interest and Performance in the Clean Energy Careers?," in ASEE Northeast Section Conference Proceedings, Boston, 2015.

[4] B. Walukevich, Assessing the Impact of Mentoring Underserved Youth through Service Learning, Education Student Publications. Paper 12, 2016.

[5] C. Herrera, J. Baldwin Grossman, T. Kauh and J. McMaken, " Raising healthy children," Child Development, vol. 82, no. 1, pp. 346-361, 2011.

[6] R. McIntyre, B. Lord, C. G. Gresky, L. L. Eyck, G. D. Frye and C. F. Bond, "A social impact trend in the effects of role models on alleviating women's mathematics stereotype threat," Current Research in Social Psychology, no. 10, Article 9, 2005.

[7] R. Robnett, P. Nelson, E. Zurbriggen, F. J. Crosby and M. M. Chemers, "Research mentoring and scientist identity: insights from undergraduates and their mentors," IJ STEM, no. Ed 5, 41, 2018.

[8] P. \&. K. Z. Lockwood, "Outstanding role models: Do they inspire or demoralize us?," in In A. Tesser, R. B. Felson, \& J. M. Suls (Eds.), Psychological perspectives on self and identity, American Psychological Association, 2000, pp. 147-171. 